\title{
ISLAM DI JAWA Hubungannya Dengan Dunia Melayu
}

\author{
Oleh: Bustamin \\ bustamin@uinjkt.ac.id
}

\begin{abstract}
Abstrak : Islam di Asia Tenggara mempunyai daya tarik untuk diteliti, karena tidak hanya sekedar tempat bagi agama besar dunia -Islam, Budha, Kristen dan Hindu-tetapi juga penyebarannya sedemikian rupa sehingga ikatan-ikatan yang mempersatukan pengikutnya dapat mengaburkan dan sekaligus menegaskan batas-batas perbedaan politis dan teritorial. Dalam masalah ini kasus Islam adalah yang paling menarik, mengingat para pengikutnya terdapat di hampir semua negara Asia Tenggara dalam jumlah yang besar. Penelusuran kembali sumber-sumber lokal yang berhubungan dengan kesultanan di Jawa menjadi penting dilakukan. Dengan penelusuran ini diharapkan akan diperoleh data dan fakta mengenai sejarah awal dan perkembangan Islam di Jawa. Data dan fakta tersebut kemudian diidentifikasi, dideskripsikan, diverifikasi, dan dihadirkan sebagai bukti sejarah yang dapat dipercaya. Dalam rangka penelusuran data dan fakta tersebut, ISMA mengadakan seminar Islam di Asia Tenggara, salah satunya adalah Islam di Jawa, yaitu datang, masuk dan berkembangnya.
\end{abstract}

Kata Kunci: Islam, Jawa, Melayu, Dunia, Sejarah

\section{A. Pendahuluan}

Sampai sekarang, sejarah masuknya dan berkembangnya Islam di Asia Tenggara, masih menjadi perdebatan dan menjadi kajian yang menarik. Permasalahannya masih berkisar kapan masuknya Islam, siapa pembawanya, wilayah mana yang pertama kali didatangi, serta bagaimana proses pengislamannya. Terkait dengan perkembangan Islam, masih menyisakan pertanyaan, seperti kapan komunitas Islam di wilayah ini mencapai kekuasaan politik, daerah mana saja yang mencapai kekuasaan, dan dalam bentuk apa kekuasaan tersebut; bagaimana kekuasaan itu diperoleh dan 
bagaimana pula hubungannya di antara berbagai wilayah yang memiliki kekuasaan politik tersebut, seperti kesultanan yang pernah ada seperti seperti Pattani di Thailand, Mindanao dan Sulu di Filipina, Malaka, Johor, serta seluruh wilayah Malaysia dan Brunei Darussalam, Tumasik di Singapura dan Camba. Begtu pula kesultanan yang pernah ada di Indonesia, seperti Samudera Pasai di Aceh, , Demak, Cirebon, Banten, Aceh Darussalam, Palembang, Riau, kesultanan di Makassar, yaitu Goa-Tallo, kesultanan di Bugis, Luwu, Bone, Soppeng dan Wajo, Ternate-Tidore, Banjar, Sumbawa, Bima, dan lain-lain di Indonesia.

Islam di Asia Tenggara mempunyai daya tarik untuk diteliti, karena tidak hanya sekedar tempat bagi agama besar dunia -Islam, Budha, Kristen dan Hindu - tetapi juga penyebarannya sedemikian rupa sehingga ikatan-ikatan yang mempersatukan pengikutnya dapat mengaburkan dan sekaligus menegaskan batas-batas perbedaan politis dan teritorial. Dalam masalah ini kasus Islam adalah yang paling menarik, mengingat para pengikutnya terdapat di hampir semua negara Asia Tenggara dalam jumlah yang besar, dan di antara beberapa negara menembus batas-batas politik yang menghalanginya". 'Tahun 1985, telah diterbitkan beberapa artikel tentang Islam di Asia Tenggara, yang memuat 32 artikel, yang dibagi atas pembahasan, yaitu Politik pada Pasca Kemer-dekaan, Pelembagaan Islam, Latar Sosio-Budaya, dan Berbagai Perspektif Mengenai Modernisasi. ${ }^{2}$ Tahun 1989, kajian Islam di Asia Tenggara kembali mendapat perhatian dari sarjana dan sejarawan Asia Tenggara, kemudian diterbitkan dalam buku bunga rampai yang diberi judul Tradisi dan Kebangkitan Islam di Asia Tenggara, ${ }^{3}$

Sekalipun sudah ada upaya unuk mengadakan kajian Islam di Asia Tenggara, tetapi sampai sekarang, masih memerlukan perhatian yang lebih besar karena sejak kajian-kajian yang telah dilakukan tersebut, masih meninggalkan persoalan terutama terkait dengan sejarah awal perkembangannya di kawasan ini. Ada beberapa alasan mengapa hal itu terjadi, antara lain: 1) Orang perlu menghabiskan waktu untuk menguasai ilmu lain, semacam bahasa Belanda, 2) Ia harus siap "berbungkus lumus" mengumpul-kan bahan-bahan atau arsip yang terpencar di mana-mana, 3) Ia juga harus siap untuk menambah tebal kaca matanya, karena matanya 
"rusak" membaca arsip dan naskah tulisan tangan yang tidak mudah dibaca dan dipahami, 4) Alasan yang tak kurang pentingnya bahwa ia harus bisa berbeda dengan apa yang pernah ditulis orang lain (khususnya sarjana asing) jika ia berharap studinya punya arti penting. ${ }^{4}$

Buku tentang Islam di Asia Tenggara, Readings on Islam in Southeast Asia memuat 32 artikel, termasuk Islam di Jawa ${ }^{5}$. Salah satu studi Kawasan Dunia Islam yang memuat Kawasan Melayu, yaitu Malaysia, Brunei Daussalam, Muangthai, Filipina, Singapura, Indonesia. Dikemukakan juga tentang Muslim Minoritas di Kamboja, tetapi tidak berbicara tentang Islam pada awal perkembangannya. ${ }^{6}$ Dalam buku Wali Songo karya Agus Sunyoto, memuat satu sub bab sekitar tiga halaman pada bab Wali Songo dan Pembentukan Masyarakat Islam Nusantara ${ }^{7}$

Penelusuran kembali sumber-sumber lokal yang berhubungan dengan kesultanan di Jawa menjadi penting dilakukan. Dengan penelusuran ini diharapkan akan diperoleh data dan fakta mengenai sejarah awal dan perkembangan Islam di Jawa. Data dan fakta tersebut kemudian diidentifikasi, dideskripsikan, diverifikasi, dan dihadirkan sebagai bukti sejarah yang dapat dipercaya. Dalam rangka penelusuran data dan fakta tersebut, ISMA mengadakan seminar Islam di Asia Tenggara, salah satunya adalah Islam di Jawa, yaitu datang, masuk dan berkembangnya.

\section{A. Jawa, Jawi dan Melayu}

Kata jawa dari yawadwipa, adalah nama Pulau Jawa dalam transkripsi Sansekerta. Dalam sajak Kakawin Hariwangsa yang ditulis Mpu Panuluh dikemukakan: Hana desa lengong leyep langonya/ ri yawadwip ${ }^{8}$ a kasanknya nusa sari/ palupuy hyang agastya tan hanoli/ ya tika trasa hilang halepnya mangke// (Ada sebuah negeri yang indah/keindahannya laksana di dalam impian, disebut Pulau Jawa, sebuah pulau yang megah. Dalam Serat Purwaka Caruban Nagari, pupuh 31-35) diceritakan bahwa Syarif Hidayatullah lebih populer dangan nama Sunan Gunung Jati (1465-1585), sebelum belajar di Jawadwipa (Jawa), ia meninggalkan negerinya (Campa) untuk menuntut ilmu pada usia 20 tahun, dan ia belajar di Mekah pada Syaikh Tajmuddin al-Kubri 
(Najmuddin al-Kubra), Syaikh Athaillah al-Syazili, dan Syaikh Ishaq (bin Ibrahim Asmoro Tuban, Jawa Timur bin Jamaluddin Husain Akbar Bugis). ${ }^{9}$ Menurut Liang Liji, Javadvipa dari kata Sanskrit, adalah pemberian nama oleh Hindu untuk menyebut Jawa atau Sumatra, sedangkan orang Tionghoa menyebut Ye Diao, karena orang Tionghoa sulit menyalin kata asing yang terdiri multi suku, sehingga sering disingkat menjadi satu atau dua suku dengan mengambil suku kata yang terkesan baginya, seperti kata Javadvipa yang terdiri atas empat suku kata, hanya disebut suku kata yang pertama dan ketiga, sehingga menjadi kata Ye Diao ${ }^{10}$

Kata jawi dinisbahkan kepada Jawani al-Kurdi, yang memerintah di Iran sekitar 301 H/931 M. Keluarga Jawani al-Kurdi datang dan menetap di Sumatra Utara, keluarga ini yang menulis aksara Arab dalam bahasa Melayu, sehingga tulisannya dinamai khath jawi, yakni tulisan Jawani.

Dalam Kitab Syarb al-Asyiqin, karya Hamzah Fansuri (dimakamkan di Ma'la, Mekah 1527), dikatakan pada pendahuluannya bahwa bahasa yang dipakai adalah bahasa Jawi, supaya orang yang tidak dapat berbahasa Arab dan Persia, dapat membaca kitab ini. Untuk jelasnya, dapat dikutip sebagai berikut :

Ketahuilah bahwa faqir dha'if Hamzah Fansuri hendak menyatakan jalan kepada allah SWT dan ma'rifat Allah dengan bahasa Jawi dalam kitab ini -insyaaallah- supaya segala hamba Allah yang tiada tahu akan bahasa Arab dan bahasa Farisi supaya dapat memicharakan dia. ${ }^{12}$

Karya Fansuri abad ke-15 tersebut memberikan informasi bahwa bahasa Arab dan Persia dipakai pada waktu itu, tetapi banyak yang tidak mengerti kedua bahasa tersebut, maka bahasa Jawi, sebagai bahasa yang umum dipakai dalam lektur. Arsyad alBanjari, juga menyebut bahasa Jawi, dan dalam kitabnya, Sabil alMuhtadin li al-Tafaquh fi al-Din, yang ditulis 27 Rabiulawal 1195/22 April 1781, dikatakan bahwa Kitab Shirath al-Mustaqim karya, Nurudin al-Raniri yang akan diterjemahkan adalah salah satu buku terbaik, yang diterjemahkan dalam bahasa Jawiyah (allugah al-Jawiyah). ${ }^{13}$ Pada perkembangan selanjutnya, kata jawi dipakai sebagai nisbah pada orang Melayu, seperti Abdushamad alFalimbani, teman Arsyad al-Banjari, dalam kitabnya Siyar alSalikin yang ditulis 1193 H/1779 M, pada lembaran awal, disebut 
dirinya sebagai penulis, Abdushamad al-Jawi al-Palembani ${ }^{14}$. seperti seorang ulama Bugis abad ke-19 yang menisbahkan dirinya kepada Jawi, sebagaimana tertulis pada kolofon Alquran yang ditulis dikatakan sebagai penulis: Zainul Abidin bin Khathib Umar al-Jawi al-Buqisi, demikian juga ulama abad ke-20, Nawawi Banten (Sunda) yang menisbahkan dirinya Nawai al-Jawi. ${ }^{15}$

Berdasarkan bukti tertulis tentang Melayu dapat di temukan pada tinggalan arkeologi yang memberi petunjuk bahwa Kerajaan Sriwijaya berada di Palembang, bagian hilir, yang berlangsung dari abad ke-7 sampai abad ke-14, kemudian dilanjutkan Kerajaan Majapahit, sampai Islam menjadi kerajaan pada abad ke-17, selanjutnya dinamai Kesultanan Palembang. Sampai kini penemuan sejumlah benda bersejarah di masa Kerajaan Sriwijaya lebih banyak di wilayah Kota Palembang. Sekurang-kurangnya sepuluh situs tinggalan Sriwijaya di Kota Palembang ${ }^{16}$. Ditemukan juga sekurang-kurangnya 13 prasasti. ${ }^{17}$ di wilayah kerajaan Kerajaan Sriwijaya ${ }^{18}$, dan parasasti tertua itu ditulis dalam bahasa Melayu.

Hubungan Dunia Melayu dengan Timur Tengah, sudah lama berlangsung, sebelum Nabi Muhammad diutus menjadi Rasul. Hal ini dapat dibuktikan adanya bahasa ajam, Melayu masuk dalam Alquran, yaitu kafur. Alquran sebagai kitab suci diturunkan kepada bangsa Arab, maka ia berbahasa Arab, sekalipun Alquran itu untuk seluruh alam ini. Salah satu bentuk kasih sayang Allah, setiap bangsa atau umat, diberi 'hikmah', seperti bangsa Persia lewat bukunya Mawaqif wa Mukhathabat dalam bahasa Persia, di Mesir lewat Atha'illah al-Sakandariaha dalam kitabnya yang sangat masyhur, yaitu al-Hikam, dan di Melayu lewat seorang Melayu Minang, Tuanku Muhammad Ali Hanafiah, dalam bukunya Kalam Iham Ilahi, di terbitkan Rabbani Press, Jakarta, 2003, kemudian diterbitkan Mizan/Hikmah Bandung 2004 dengan judul Sastra Ilahi: Bagi Pencari Tuhan, terakhir diterbitkan oleh Rabbani Press Jakarta 2012 dengan terjemahannya dalam bahasa Inggris dengan judul Inilah AKU: Pencerahan Rohani bagi Pencari Tuhan (Here I AM: Enlightenment of the Seeker of God). Dibawah ini di kutip salah satu dari bab pengetahuan: 
Wahai Hambaku:

Pengetahuan-Ku tidak mencari huruf dalam ia bernyata, melainkan huruf dan bilangan yang mencarinya.

Maka janganlah sekali-kali engkau mendatangi- $\mathrm{Ku}$, dengan segala bentuk huruf dalam bilangan, karena ia akan menghijabmu dalam kata dan hitungan.

Ketika engkau ingin dapat mengenal tanpa pengenalan, serta berjalan kepada-Ku tanpa jarak yang dapat ditafsirkan, yakni apabila semata-mata engkau jadikan rasamu tempat engkau mendatangi-Ku sehingga cukuplah dengan pengetahuannya (rasa) engkau mengetahui keberadaanya

\section{B. Kedatangan Islam}

Mengenai islamisasi di satu daerah, Menurut Noordoyn:

Hubungan dengan proses Islamisasi Indonesia, dapat dilihat dua tahap jang terpisah dengan djelas: datangnja Agama Islam dan masuknja Agama Islam, jang pertama adalah sebagian dari sedjarah pergerakan perniagaan diseluruh nusantara, jang kedua terdiri atas bagian2 waktu tersendiri dari sedjarah pelbagai sukubangsa Indonesia, djadi jang dapat diuraikan dalam monografi2 pendek jang terpisah, dengan alasan2nja sendiri menurut daerah, dan paling tinggi disertai suatu pola umum jang kebanjakan mudah dikenali, djika perlu disusul dengan tahap ke-tiga: penjebaran Agama Islam, sekarang dengan kekerasan (sendjata), jang bertolak dari daerah2 jang pertama-tama di Islamkan kenegeri-negeri dan kelompok2-suku didekatnya ${ }^{19}$.

Berbicara tentang masuknya Islam di satu daerah dapat dibedakan, pertama, masuknya Islam dalam arti ada orang Islam masuk di satu wilayah, kedua, adanya penduduk setempat menerima Islam, dan ketiga, Islam dijadikan sebagai agama Kerajaan. Hasil seminar masukknya Islam di Indonesia, ditetapkan bahwa Islam masuk sejak abad pertama Hijriah atau abad ke-7 masehi, dalam arti adanya orang Islam dari luar masuk ke Indonesia, dalam kategori pertama.

Dalam kitab Nukhbah al-Dahr fi 'Aja'ib al-Bar wa al-Bahr karya Syamsuddin Ad-Damasyqi (W.1326 M) disebutkan bahwa 
Islam telah tiba di Indonesia pada tahun $30 \mathrm{H}(651 \mathrm{M})$. Pada masa pemerintahan Utsman bin Affan ${ }^{20}$. Menurut Al-Haddad, pada zaman Khalifah Utsman bin Affan, rupanya Khalifah Utsman mengirim utusan ke Jawa dan pulau-pulau sekitarnya. Perjalanan perutusan itu menghabiskan waktu selama empat tahun ${ }^{21}$

Dalam Historiografi Islam di Jawa diperoleh data bahwa pada masa Dinasti Amawiyah (661 M-749 M), sudah ada kontak dengan kerajaan di Jawa, dimana Raja Jawa, Sri Indrawan mengirim surat kepada Umar bin Abdul Azis, dan ia menceritakan bahwa ia memiliki ribuan gajah, rempah-rempah, wewangian, dan kapur barus. Raja juga menulis dalam suratnya bahwa kotanya dilintasi dua sungai yang mengairi lahan pertanian. Surat itu berfungsi sebagai penganar atas hadiah yang diberikan kepada Umar bin Abdul Azis. Umar bin Abdul Aziz memberikan pula hadiah sebagai balasan seorang Zanji (budak wanita kulit hitam). ${ }^{22}$ Hubungan Dinasti Muawiyah dengan kerajaan Nusanara dapat ditemukan juga dari sumber Arab, yaitu dalam kitab al-'Iqd alFarid, karya Ibn Abdur Rab (246-329/860-940), surat yang dialamatkan kepada Umar bin Abdul Azis (99-102/717-720), menunjukan betapa hebatnya Maharaja dan kerajaannya:

Nu'aim bin Hammad menulis: "Raja al-Hind (Kepulauan) mengirim sepucuk surat kepada Umar bin Abdul Azis, yang berbunyi sebagai berikut: "Dari Raja di Raja [Malik al-Amlak= Maharaja]; yang adalah keturunan seribu raja; yang isterinya juga adalah anak cucu seribu raja; yang di dalam kandang binatangnya terdapat seribu gajah; yang di wilayahnya terdapat dua sungai yang mengairi pohon gaharu, bumbu-bumbu wawangian, pala, dan kapur barus yang semerbak wawangiannya sampai menjang-kau jarak 12 mil; kepada Raja Arab [Umar bin Abdul Azis], yang tidak menyekutukan tuhan-tuhan lain dengan Tuhan. Saya telah mengirimkan kepada Anda hadiah, yang sebenarnya merupakan hadiah yang taka begitu banyak, tetapi sekedar tanda persahabatan; dan saya ingin Anda mengirimkan kepada saya tentang hukumhukumnya [atau di dalam versi lain, yang akan mengajarkan Islam dan menjelaskan kepada saya.

Ibnu Tighribirdi (813-74/1410-1470) mengutip surat ini dalam karyanya, al-Nujum al-Zhahirah fi Muluk Mishr wa al-Qahirah, 
melalui karya Ibn Asakir (499-571/1105-76), memberikan tambahan kalimat yang menarik menjelang akhir surat itu:" Saya mengirimkan hadiah kepada Anda berupa bahan wangian, sawo, kemenyan dan kapur barus. Terimalah hadiah itu, karean saya adalah saudara Anda dalam Islam. Surat itu diterima Umar bin Abdul Azis tahun 100/718. ${ }^{23}$

Menurut P. Wheatley, dalam bukunya The Golden Kerssonese: Studies in the Historical Geography of Malay Peninsula Before A.D. 1500, dikatakan yang paling awal membawa seruan Islam ke Nusantara adalah saudagar Islam yang sudah membangun jalur perhubungan dagang dengan Nusantara, jauh sebelum Islam. Kehadiran saudagar Arab di Kerajaan Kalingga abad ke-7, yaitu era kekuasaan Rani Shima. Sedangkan di Sriwijaya sendiri, Maharaja yang berkuasa pada waktu itu adalah Sri Indravarman, yang disebut sumber-sumber Cina sebagai Shi-li-t'o-pa-mo. Nama Cinanya ini mengisyaratkan bahwa ia belum lagi menjadi pemeluk Islam. ${ }^{24}$

\section{Masuknya Islam}

Kontak Islam dengan Nusantara, terjadi juga pada masa Kesultanan Turki Usmani (1299-1923) dengan kepulauan Nusantara. Sultan Muhammad 1 (1413-1421) memerintah kerajaan Turki Usmani, mengirim muballig ke Jawa, setelah ia mendapat informasi tentang Islam dari pedagang Gujarat. Muballig yang akan dikirim diambil dari berbagai wilayah kekuasaannya, Afrika Utara dan Timur Tengah, kemudian terkumpul sembilan ulama yang dianggap memiliki kemampuan menjadi muballig dan memiliki kekeramatan, dikirim ke Pulau Jawa, kemudian dinamai wali songo, yang dibagi atas beberapa periode yaitu:

\section{Walisongo Periode Pertama}

1. Maulana Malik Ibrahim, berasal dari Turki ahli mengatur negara. Berdakwah di Jawa bagian timur. Wafat di Gresik pada tahun 1419 M. Makamnya terletak satu kilometer dari sebelah utara pabrik Semen Gresik.

2. Maulana Ishak berasal dari Samarqand (dekat Bukhara-Rusia Selatan). Beliau ahli pengobatan. Setelah tugasnya di Jawa selesai Maulana Ishak pindah ke Pasai dan wafat di sana. 
3. Maulana Ahmad Jumadil Kubra, berasal dari Mesir. Beliau berdakwah keliling. Makamnya di Troloyo Trowulan, Mojokerto Jawa Timur.

4. Maulana Muhammad Al Maghrobi, berasal dari Maghrib (Maroko), beliau berdakwah keliling. Wafat tahun $1465 \mathrm{M}$. Makamnya di Jatinom Klaten, Jawa Tengah.

5. Maulana Malik Isroil berasal dari Turki, ahli mengatur negara. Wafat tahun 1435 M. Makamnya di Gunung Santri.

6. Maulana Muhammad Ali Akbar, berasal dari Persia (Iran). Ahli pengobatan. Wafat 1435 M. Makamnya di Gunung Santri.

7. Maulana Hasanuddin berasal dari Palestina. Berdakwah keliling. Wafat pada tahun 1462 M. Makamnya disamping masjid Banten Lama.

8. Maulana Alayuddin berasal dari Palestina. Berdakwah keliling. Wafat pada tahun 1462 M. Makamnya disamping masjid Banten Lama.

9. Syekh Subakir, berasal dari Persia, ahli menumbali (metode rukyah) tanah angker yang dihuni jin-jin jahat tukang menyesatkan manusia. Setelah para Jin tadi menyingkir dan lalu tanah yang telah netral dijadikan pesantren. Setelah banyak tempat yang ditumbali (dengan Rajah Asma Suci) maka Syekh Subakir kembali ke Persia pada tahun 1462 M dan wafat di sana. Salah seorang pengikut atau sahabat Syekh Subakir tersebut ada di sebelah utara Pemandian Blitar, Jawa Timur. Disana ada peninggalan Syekh Subakir berupa sajadah yang terbuat dari batu kuno.

\section{Walisongo Periode Kedua}

Pada periode kedua ini masuklah tiga orang wali menggantikan tiga wali yang wafat. Ketiganya adalah:

1. Raden Ahmad Ali Rahmatullah, datang ke Jawa pada tahun 1421 M menggantikan Malik Ibrahim yang wafat pada tahun 1419 M. Raden Ahmad berasal dari Cempa, Muangthai Selatan (Thailand Selatan).

2. Sayyid Ja'far Shodiq berasal dari Palestina, datang di Jawa tahun 1436 menggantikan Malik Isro'il yang wafat pada tahun 
1435 M. Beliau tinggal di Kudus sehingga dikenal dengan Sunan Kudus.

3. Syarif Hidayatullah, berasal dari Palestina. Datang di Jawa pada tahun $1436 \mathrm{M}$. Menggantikan Maulana Ali Akbar yang wafat tahun $1435 \mathrm{M}$. Sidang walisongo yang kedua ini diadakan di Ampel Surabaya.

Para wali kemudian membagi tugas. Sunan Ampel, Maulana Ishaq dan Maulana Jumadil Kubro bertugas di Jawa Timur. Sunan Kudus, Syekh Subakir dan Maulana Al-Maghrobi bertugas di Jawa Tengah. Syarif Hidayatullah, Maulana Hasanuddin dan Maulana Aliyuddin di Jawa Barat.

\section{Walisongo Periode Ketiga}

Pada tahun 1463 M. Masuklah empat wali menjadi anggota Walisongo yaitu:

1. Raden Paku atau Syekh Maulana Ainul Yaqin kelahiran Blambangan Jawa Timur. Putra dari Syekh Maulana Ishak dengan putri Kerajaan Blambangan bernama Dewi Sekardadu atau Dewi Kasiyan. Raden Paku ini menggantikan kedudukan ayahnya yang telah pindah ke negeri Pasai. Karena Raden Paku tinggal di Giri maka beliau lebih terkenal dengan sebutan Sunan Giri. Makamnya terletak di Gresik Jawa Timur.

2. Raden Said, atau Sunan Kalijaga, kelahiran Tuban Jawa Timur. Beliau adalah putra Adipati Wilatikta yang berkedudukan di Tuban. Sunan Kalijaga menggantikan Syekh Subakir yang kembali ke Persia.

3. Raden Makdum Ibrahim, atau Sunan Bonang, lahir di Ampel Surabaya. Beliau adalah putra Sunan Ampel, Sunan Bonang menggantikan kedudukan Maulana Hasanuddin yang wafat pada tahun 1462. Sidang Walisongo yang ketiga ini juga berlangsung di Ampel Surabaya.

\section{Walisongo Periode Keempat}

Pada tahun 1466 diangkat dua wali menggantikan dua yang telah wafat yaitu Maulana Ahmad Jumadil Kubro dan Maulana Muhammad Maghrobi. Dua wali yang menggantikannya ialah:

1. Raden atau Raden Fattah (Raden Patah) Raden Patah adalah murid Sunan Ampel, beliau adalah putra Raja Brawijaya Majapahit. Beliau diangkat sebagai Adipati Bintoro pada 
tahun 1462 M. Kemudian membangun Masjid Demak pada tahun 1465 dan dinobatkan sebagai Raja atau Sultan Demak pada tahun 1468 .

2. Fathullah Khan, putra Sunan Gunungjati, beliau dipilih sebagai anggota Walisongo menggantikan ayahnya yang telah berusia lanjut.

\section{Walisongo Periode Kelima}

Periode ini masuk Sunan Muria atau Raden Umar Said, putra Sunan Kalijaga menggantikan wali yang wafat. Syekh Siti Jenar atau Syekh Lemah Abang itu adalah salah satu anggota Walisongo, namun karena Siti Jenar di kemudian hari mengajarkan ajaran yang menimbulkan keresahan umat, kareana ajarnnya ber-hubungan dengan hakekat yang belum dapat diterima oleh masyarakat umum, maka digantikan oleh Sunan Bayat - bekas Adipati Semarang (Ki Pandanarang), murid Sunan Kalijaga. Akan tetapi Walisongo yang dikenal sekarang adalah wali yang sembilan, yaitu:

1. Syekh Maulana Malik Ibrahim

2. Sunan Ampel

3. Sunan Bonang

4. Sunan Giri

5. Sunan Drajad

6. Sunan Muria

7. Sunan Kudus

8. Sunan Kalijaga

9. Sunan Gunungjati ${ }^{25}$

Saya cenderung dengan pendapat bahwa istilah wali songo, (sembilan wali), tidak tepat, karena wali yang disebut di atas jumlahnya lebih dari sembilan. Kata songo seharusnya dibaca tsana, dari bahasa Arab yang artinya terpuji. Jadi, wali tsana artinya wali terpuji. Hal ini didukung adanya babad yang dinamai walitsana dimana wali yang diceritakan di dalamnya tidak berjumlah sembilan, tetapi delapan. Pemakaian kata tsana dipakai juga dikalangan Bugis-Makassar dan Mandar di Sulawesi, yaitu sulesana, dari dua kata, zu tsana (mempunyai pujian), ada sulesana, artinya kata terpuji, maksudnya kata berhikmah. 


\section{Penyebaran Islam}

Jauh sebelum Maulana Malik Ibrahim datang ke Pulau Jawa, sebenarnya sudah ada masyarakat Islam di daerah-daerah pantai utara, termasuk di desa Leran, Jawa Timur, tidak jauh dari Surabaya $^{26}$. Hal itu bisa dibuktikan dengan adanya makam seorang wanita bernama Fatimah Binti Maimun yang meninggal pada tahun 475 Hijriyyah atau pada tahun $1082 \mathrm{M}$, dan inskripsi ini yang tertua di Indonesia.

Kerajaan Majapahit (1293-1500) yang biasanya dihubungkan dengan Hindu-Budha ${ }^{27}$, tetapi beberapa tulisan berdasarkan fakta bahwa kerajaan ini adalah salah satu kesultanan di Nusantara. Salah satu tokoh Majapahit adalah Mahapati Gajah Mada (13131364 M) yang dilukiskan dalam Kakawin Negara Kertagama, karya pendeta Hindu yang dikeluarkan dari Kerajaan Majapahit, yaitu Nadenra, nama samarannya, Parapanca yang digubah 1365. Dan ia tidak menyebut sedikit pun tentang Islam. Parapanca melukiskan Gajah Mada dengan berbagai gelar, seperti Pati Wilwatikta, Menteri Wira (pupuh 12/4), Patih Amangkubumi (pupuh 63/1), Patih Mangkubumi (pupuh 66/2), Adimenteri (pupuh 71/3. Digambarkan Gajah Mada memiliki sifat delapan terpuji sebagai-mana tertulis pada pupuh 12/4, yaitu: bijaksana, cerdik, jujur, fasih berbicara, teguh, tangkas, tenang, cerdas, cinta kepada sesama tanpa pandang bulu. Ia insaf bahwa hidup ini tidak baka, karenanya tiap hari berbuat kebajikan (pupuh 71). ${ }^{28}$ Gajah Mada membuktikan cita-citanya untuk mempersatukan Nusantara dengan nazarnya yang dikenal sumpah palapa. Jasa Gajah Mada menjadikan Negara Majapahit sejahtera, sehingga berduyun-duyun tamu asing datang berkunjung, yaitu Jambudwipa, Kamboja, Cina, Yamana, Campa, Kamataka, Goda, Saim (pupuh 83/1). Selain menjalin hubungan dengan negara asing, Majapahit, terutama pada masa Gajah Mada telah melakukan perluasan kekuasan, sehingga pengaruh Gajah Mada meluas, sampa negeri Malaysia sekarang, yaitu Langkasuka, Saimwang, Kelantan, Terengganu, Johor, Tumasik, Kelang, Kedah (pupuh 14/1-2), Di Sumatra, disebutkan dalam Negara Kertagama sebagai negara bawahan, yaitu Jambi, Palembang, Toba, Darmasraya, Kendis, Kahwas, Minangkabau, Siak, Kampar, Pane, Lawas, Samudra, Lamuri, Batan, Lampung, Barus, Kapuas, Lingga. Di Kalimantan isebut, Sampit, Kota 
Lingga, Kota Waringin, Sambas Lawai. (pupuh 13/1-2). Pada pupuh14 banyak sekali disebut negara bawahannya di kawasan Timur, yaitu Makassar, Bantaen, Luwu, Selayar, Buton, Banggae (Sulawesi), Maluku, dan Papua.

Di antara fakta Kesultanan Majapahit, diangkatnya Maulana Malik Ibrahim sebagai kadi pada Kesultanan Majapahit. Ia lebih dikenal penduduk setempat sebagai Kakek Bantal itu datang ke Gresik pada tahun 1404 M, beliau berdakwah di Gresik hingga akhir wafatnya yaitu pada tahun 1419. Keterangan yang tertulis pada makamnya ialah sebagai berikut: "Inilah makam Almarhum Almaghfur yang berharap rahmat Tuhan kebanggaan para Pangeran, sendi para Sultan dan para Menteri, penolong para fakir miskin, yang berbahagia lagi syahid, cemerlangnya symbol negara dan agama, Malik Ibrahim yang terkenal dengan Kakek Bantal. Allah meliputinya dengan RahmatNYA dan keridhaanNYA, dan dimasukkan ke dalam surga. Telah wafat pada hari Senin 12 Rabiul Awwal tahun 822 H" (8 April 1419)

Ditemukan juga koin bertuliskan laialaha illallah, dan lambang Majapahit berupa delapan sinar matahari dengan tulisan Arab: shifat, asma, marifat, Adam, Muhammad, Allah, tauhid, dan zat.

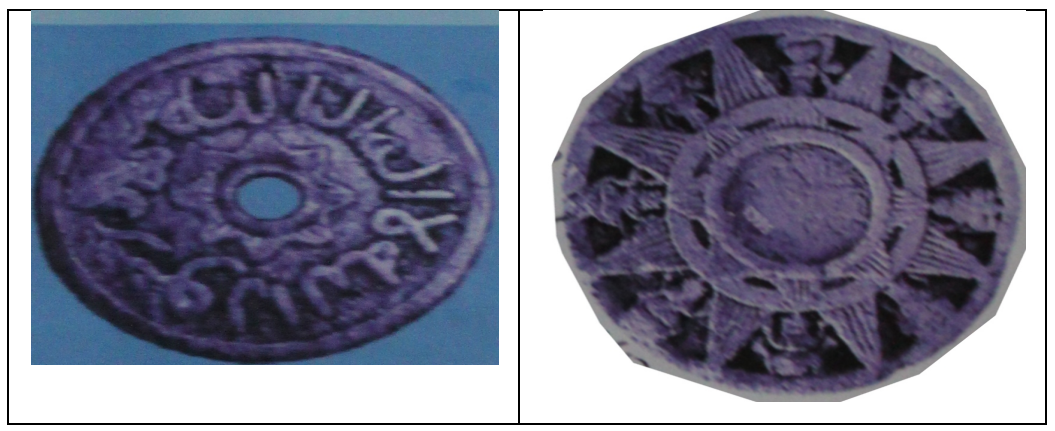




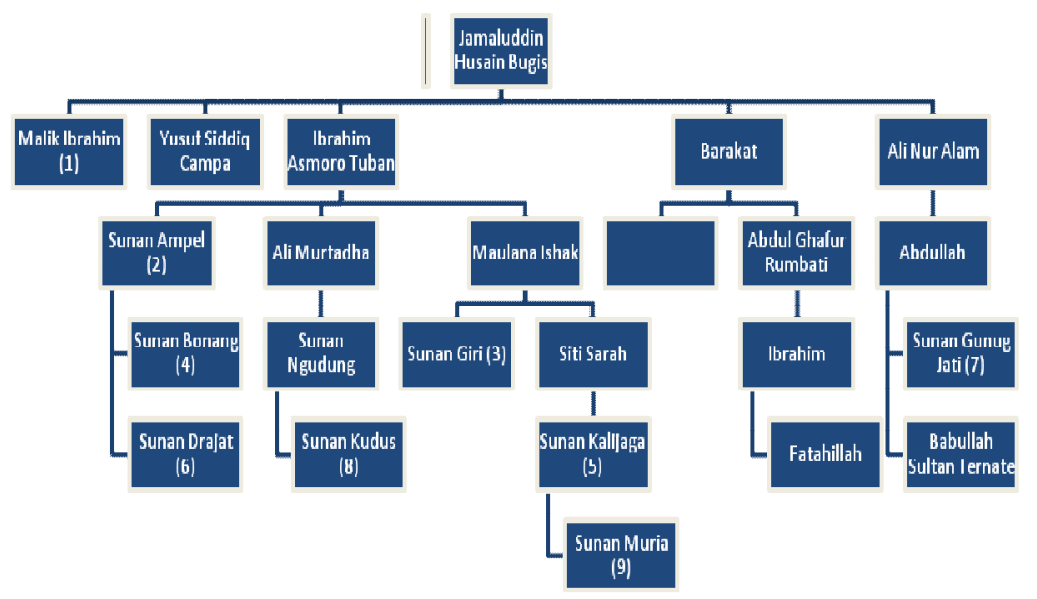

Seorang Raja Majapahit yang berjasa menyebarkan Islam adalah Brawijaya V, banyak isterinya, 117 anaknya. Salah satu isterinya dikenal putri Campa Ratu Andrawati (Aisyah) putri Maulana Ishak, menjadi penguasa di antaranya, 1) Raden Fatah kemudian mendirikan Kesultanan Demak sebagai kelanjutan Kesultanan Majapahit, 2) Ratu Retna Pembayun/Sekar Kedhaton kawin dengan Prabu Handayaningrat di Pengging, melahirkan Mas Karebet/Jaka Tingkir/Abdurrahman. Jaka Tingkir/Abdurrahman kawin dengan Mas Ratu Ayu, putri Sultan Demak III, Raden Trenggana bin Raden Fatah, kemudian menjadi Raja di Kesultanan Pajang (kelanjutan Kesultanan Demak) dengan gelar Sultan Hadiwijaya 3) Raden Jaka Peteng atau Raden Harya Lembupeteng Adipati Madura.

Keturunan Ratu Andrawati (Aisyah) yang nikah dengan Brawijaya $\mathrm{V}$, disebut ahlul bait (keturunan Nabi), atau Alawiyin, yang dinisbahkan dari keturunan Nabi melalui Husain, ke-12, cucu Ahmad al-Muhajir, urutan ke-10, anak Ubaidillah, ke11. Dapat dilihat silsilah di bawah ini:

1. Muhammad SAW., Madinah

2. Fatimah Az-Zuhra, Madinah

3. Husain bin Ali, Karbala Iraq

4. Ali Zainal Abidin,Madinah

5. Muhammad Al-Baqir, Madinah

6. Ja'far Ash-Shadiq, Madinah 
7. Ali Al-Uraidhi, Madinah

8. Muahammad An-Naqib, Basrah, Irak

9. Isa, Basrah, Irak

\section{Ahmad Al-Muhajir,}

11. Ubaidillah, Hadramaut

12. Alawi, Sahal, Yaman

Alawiyyin mendirikan kesultanan, di Timur tengah, India, dan Asia Tenggara.

Di bawah ini dikemukakan kesultanan yang didirikan golongan Alawiyin di Asia Tenggara:

1. Nama Kerajaan : Kesulthanan Perlak (Aceh)

Dinasti Yang Memerintah: Dinasti Ahlul Bait pertama di dunia sejak zaman tabiin-tabiin tahun 849M-918M yang berada di Nusantara (Aceh) Zuriyah Sulthan Alaidin Sayyid Maulana Abdul Aziz Shah bin 'Ali Muktabar bin Muhammad Diba'I bin Jafar Ash-Sadiq (marganya masih Al-Husaini).

Lokasi Kerajaan : Aceh, (Indonesia).

Kekusaan Kerajaan : Aceh (Indonesia).

Kesulthanan Perlak (Aceh)hanya bertahan 4 generasi saja, lalu Aceh dikuasai oleh Kesulthan Samu Zuriyaha Pasai, dan Kesulthanan Perlak (Aceh) Zuriyah Sulthan Alaidin Sayyid Maulana Abdul Aziz Shah bin 'Ali Muktabar belum ada marganya dan luar dari marga Ba 'Alawiyy (keturunan Alwiy bin Ubaydillah) jadi marganya masih Al-Hussaini diambil dari nama eyang buyutnya-nya Al-Imam Sayyidina Hussain AsSabibti RA

2. Nama Kerajaan: Kesulthanan Jambi

Dinasti Yang Memerintah : Zuriyah Sayyid Al-Jaelani (Dzuriah syekh Abdul Qodir Al-Jaelani, Dzuriah Imam Hasan bin Imam Ali KW).

Lokasi Kerajaan : Jambi, Indonesia.

Kekusaan Kerajaan : Jambi, (Indonesia).

3. Nama Kerajaan : Kesulthanan Campa (Kamboja)

Dinasti Yang Memerintah: Ba 'Alwi Dinasti Azmatkhan.

Lokasi Kerajaan : Campa (Kamboja).

Kekusaan Kerajaan : Campa (Kamboja) 
Keterangan Sejarah : Setelah masa abad 20M Kesulthanan Campa (Kamboja) dikusai oleh Kerajan Campa Zuriyah dinasti Campa yang beragama Budha dan umat Islam Kesulthanan Campa (Kamboja) mengalami pembantaian pada saat pembe-rontak Komunis Kemer mengusai Kamboja diperkirakan 7 hingan 9 juta orang Muslim menjadi korban kekejaman Kemer ini.

4. Nama Kerajaan : Kesulthanan Patani (Thailand)

Dinasti Yang Memerintah: Ba ' Alwi Dinasti Azmatkhan.

Lokasi Kerajaan : Patani (Thailand Selatan).

Kekusaan Kerajaan : Propisi Patani (Thailand Selatan)

Keterangan Sejarah : Kesulthanan Patani (Thailand) pada masa sekarang dikusai oleh Kerajaan Siam (Dinasti Siam Thailand (Kerajaan Budha)).

5. Nama Kerajaan : Kesulthanan Brunai Darusalam

Dinasti Yang Memerintah: Zuriyah Dinasti Qitadah (Zuriyah dzuriah Imam Hasan).

Lokasi Kerajaan : Negara Brunai Darusalam.

Kekusaan Kerajaan : Negara Brunai Darusalam.

Keterangan Sejarah : Kesulthanan Brunai Darusalam pernah ditaklukan oleh Kerajaan Inggris hinga pada akhirnya diberikan kemerdekaan dibawah kekuasaan Inggris (Dominion) yang tergabung dalam Negara kesatuan Malaysia yang mempunyai 12 Propinsi yang 10 Propinsinya dikuasai oleh Yang Dipertuan Agoeng Malaysia (para Sulthan) setelah itu Kesulthanan Brunai Darusalam memisahkan diri dari Negara kesatuan Malaysia sama dengan Singapura yang dikuasai oleh Gubernur.

6. Nama Kerajaan : Kesulthanan Cirebon Larang/Carbon Larang Dinasti Yang Memerintah: Ba 'Alwi Dinasti Azmatkhan.

Lokasi Kerajaan : Kota Cirbon larang (Indonesia).

Kekusaan Kerajaan : Cirebon Larang, Sunda, dan Banten pada Saat Sulthan Ratu Haji Sri Himun Syarif Hidayatullah Susuhunan Gunung Jati berkuasa setelah itu Kekusaan Kerajaan Kesultanan Cirebon larang hanya menguasai Cirebon Larang.

Keterangan Sejarah : Setelah Sulthan Ratu Haji Sri Himun Syarif Hidayatullah Susuhunan Gunung Jati meninggal dunia 
selang beberapa generasi Kesulthanan Cirebon Larang terpecah menjadi Kesulthanan Kasepuhan Cirebon, Kesulthanan Kanoman Cirebon, Kesulthanan Kaprabon Cirebon, dan Kesulthanan Kacirebonan Cirebon lalu sekarang hanya menjadi lembaga adat dan kebudayan dalam Negara Kesatuan Republik Indonesia (NKRI). Kesulthanan Cirebon Larang terbagi dalam 4 keraton yakni : Keraton Kasepuhan, Keratonn Kanoman, Keraton Kaprabon, Keraton Kacirebonan.

7. Nama Kerajaan : Kesulthanan Kasepuhan (Cirebon)

Dinasti Yang Memerintah: Zuriyah Ba 'Alwi Dinasti Azmatkhan Alhussaini.

Lokasi Kerajaan : Cirebon, Jawa Barat, (Indonesia).

Kekusaan Kerajaan : Cirebon, Jawa Barat, (Indonesia).

Keterangan Sejarah: Pecahan Kesultanan Cirebon Lararang

8. Nama Kerajaan : Kesulthanan Kanoman (Cirebon)

Dinasti Yang Memerintah: Zuriyah $\mathrm{Ba}$ 'Alwi Dinasti Azmatkhan Alhussaini.

Lokasi Kerajaan : Cirebon, Jawa Barat, (Indonesia).

Kekusaan Kerajaan : Cirebon, Jawa Barat, (Indonesia).

Keterangan Sejarah: Pecahan Kesultanan Cirebon Lararang

9. Nama Kerajaan : Kesulthanan Kaprabon (Cirebon)

Dinasti Yang Memerintah: Zuriyah $\mathrm{Ba}$ 'Alwi Dinasti Azmatkhan Alhussaini.

Lokasi Kerajaan : Cirebon, Jawa Barat, (Indonesia).

Kekusaan Kerajaan : Cirebon, Jawa Barat, (Indonesia).

Keterangan Sejarah: Pecahan Kesultanan Cirebon Lararang

10. Nama Kerajaan : Kesulthanan Kacirebonan (Cirebon)

Dinasti Yang Memerintah: Zuriyah $\mathrm{Ba}$ 'Alwi Dinasti Azmatkhan Alhussaini.

Lokasi Kerajaan : Cirebon, Jawa Barat, (Indonesia).

Kekusaan Kerajaan : Cirebon, Jawa Barat, (Indonesia).

Keterangan Sejarah: Pecahan Kesultanan Cirebon Lararang

11. Nama Kerajaan : Kesulthanan Sumedang Larang / Sunda Larang

Dinasti Yang Memerintah: Ba ‘ Alwi Dinasti Azmatkhan.

Lokasi Kerajaan : Kota Sumedang (Indonesia). 
Kekusaan Kerajaan : Meliputi Kota : Sumedang, Bandung, Tasikmalaya, Garut dan Cianjur.

Keterangan Sejarah : Menjadi adipati (Negara Bawahan) Kesulthanan Cirebon Larang (pada masa Sultan Ratu Haji Sri Himun Syarif Hidayatullah berkuasa) setelah itu Kesulthanan Sumedang Larang mendapatkan kemerdekan atas amanat Syarif Hidayatullah Sebelum beliu meninggal dunia. Setelah itu dikusai oleh pengusaan Mataram Islam, penguasan VOC lalu penguasaan Kolonial Kerajan Belanda (Nederland). Lalu setelah Repbulik Indonesia Serikat menjadi salah satu negara bagian Repbulik Indonesia Serikat dan sekarang hanya menjadi lembaga adat dan kebudayan dalam Negara Kesatuan Republik Indonesia (NKRI)

12. Nama Kerajaan : Kesulthanan Banten

Dinasti Yang Memerintah: Ba 'Alwi Dinasti Azmatkhan.

Lokasi Kerajaan : Kota Banten (Indonesia).

Kekusaan Kerajaan : Kota Banten, Bogor, Sukabumi, dan Bekasi (Indonesia).

Keterangan Sejarah : Menjadi adipati (Negara Bawahan) Kesulthanan Cirebon Larang (pada masa Sultan Ratu Haji Syarif Hidayatullah berkuasa) setelah itu Kesulthanan Banten mendapatkan kemerdekan atas amanat Sulthan Ratu Haji Sri Himun Syarif Hidayatullah Sebelum beliu meninggal dunia. Lalu dihancur leburkan oleh VOC lalu penguasaan Kolonial Kerajan Belanda (Nederland) sehingga Kesulthanan Banten hancur lebur hingga mengebabkan Keraton Kesulthanan Banten tersisa puing-pungnya saja karena Kesulthanan Banten tidak mau tunduk pada VOC dan Kolonial Kerajan Belanda (Nederland).

13. Nama Kerajaan : Kesulthanan Adipati Jayakarta

Dinasti Yang Memerintah: Ba ' Alwi Dinasti Azmatkhan.

Lokasi Kerajaan : Kota Jakarta (Indonesia).

Kekusaan Kerajaan : Kota Jakarta (Indonesia).

Keterangan Sejarah : Diberikan kekusana atas Kota Jayakarta oleh Sultan Ratu Haji Sri Himun Syarif Hidayatullah Susuhunan Gunung Jati setelah beliu meninggal pada Pageran Jayakarta yang menjadi Adipati (negara bawahan) Zuriyah Kesulthanan Banten. 
14. Nama Kerajaan : Kesulthanan Adipati Pakuan

Dinasti Yang Memerintah : Zuriyah Al-Muhqrowi (AlHussaini Persia) tetapi dikenal juga ada tautan Zuriyah pihak wanita Zuriyah Azmatkhan dan Al-Jaelani Lokasi Kerajaan :Bogor, Jawa Barat, (Indonesia).

Kekusaan Kerajaan : Bogor, Jawa Barat, (Indonesia).

15. Nama Kerajaan : Kesulthanan Kesulthanan Demak Bintoro

Dinasti Yang Memerintah: Zuriyah Al Muhqrowi (Al-Hussaini Persia) tetapi dikenal memiliki tautan Zuriyah garis wanita Zuriyah $\mathrm{Ba}$ 'Alwi Dinasti Azmatkhan.

Lokasi Kerajaan : Demak Jawa Tengah (Indonesia).

Kekusaan Kerajaan : Mewarisi kekuasaan Kerjaan Majapahit di pulau Jawa

Keterangan Sejarah : Mewarisi kekuasaan Kerjaan Majapahit di pulau jawa sampai Kesulthanan Demak Bintoro takluk oleh kekuasan Kesulthanan Mataram Islam, penguasan VOC lalu penguasaan Kolonial Kerajan Belanda (Nederland).

16. Nama Kerajaan : Kesulthanan Giri Kedaton

Dinasti Yang Memerintah: Ba 'Alwi Dinasti Azmatkhan.

Lokasi Kerajaan : Gersik, Jawa Timur (Indonesia)

Kekusaan Kerajaan : Gersik, Jawa Timur (Indonesia),

Keterangan Sejarah : Pada saat Kesulthanan Giri Kedaton berjaya di bawah kekuasaan pemerintahan Teokrasi (pemerintah agama) ditangan Sulthan Sunan Giri Negara Kesulthanan Giri Kedaton ini menjadi Negara yang berbasis syariat Islam sama seperti Kesulthanan Ampel Denta dan sebagai Negara yang membaiat Negara-negara Islam lainya untuk memnunjukan keabsyahan (Dee Yuure) dinasti Islam di pulau Jawa selain para Dinasti Syaid yang berada di Timur Tengah lalu setelah beberapa generasi Kesulthanan Giri Kedaton di taklukan oleh Mataram Islam.

17. Nama Kerajaan : Kesulthanan Ampel Denta (Surabaya) Dinasti Yang Memerintah: Ba ' Alwi Dinasti Azmatkhan. Lokasi Kerajaan : Ampel Denta (Surabaya). Kekusaan Kerajaan : Ampel Denta (Surabaya). Keterangan Sejarah : Kesulthanan Ampel Denta (Surabaya) adalah pemerintahan Teokrasi (pemerintah agama) di tangan 
Sulthan Sunan Ampel Denta (Syekh Makhdum Ibrahim Asmarkhandy) ditangan beliu Kesulthanan Ampel Denta (Surabaya) ini menjadi Negara yang berbasis syariat Islam sama seperti Kesulthanan Giri Kedaton dan sebagai Negara yang membaiat Negara-negara Islam lainya untuk menunjukkan keabsyahan (Dee Yuure) dinasti Islam di pulau Jawa selain para Dinasti Syaid yang berada di Timur Tengah.

18. Nama Kerajaan : Kesulthanan Surabaya

Dinasti Yang Memerintah: Ba 'Alwi Dinasti Azmatkhan.

Lokasi Kerajaan : Ampel Denta (Surabaya).

Kekusaan Kerajaan : Ampel Denta (Surabaya).

Keterangan Sejarah : Menuruskan perjuangan Sunan Ampel dan meneruskan Negara Kesulthanan Ampel Denta (Surabaya) menjadi Negara Teokrasi (pemerintah agama) dipulau jawa hinga 3 generasi lalu dihancurkan oleh Mataram Islam.

19. Nama Kerajaan : Kesulthanan Adipati Pajan

Dinasti Yang Memerintah: Ba 'Alwi Dinasti Azmatkhan. Lokasi Kerajaan : Pengging / Tingkir, Jawa timur (Indonesia). Kekusaan Kerajaan : Pengging/Tingkir, Jawa timur (Indonesia).

Keterangan Sejarah : Mewarisi / meneruskan Kesulthanan Pengging menjadi Adipati (Negara Bawahan) Kesultanan Demak Bintoro, dibawah kekuasaan Raden Mas Karebet @ Pendekar Jaka Tingkir@ Sulthan Hadi Wijaya bin Ki Kebo Kenanga hinga akhirnya dihancurkan oleh bala tentara Kesultanan Demak Bintoro karena melakukan makar / pemberontakan.

20. Nama Kerajaan : Kesulthanan Mataram Islam

Dinasti Yang Memerintah: Ada tautan Zuriyah pihak wanita Zuriyah Ba 'Alwi Dinasti Azmatkhan.

Lokasi Kerajaan : Yogyakarta (Indonesia).

Kekusaan Kerajaan : Jawa Tengah, Jawa Timur lalu melakukan expansi ke Jawa Barat DLL.

Keterangan Sejarah : Merebut kekuasaan Kesulthanan Demak Bintoro dan melakukan expansi hinga mengusai Kesulthanan Cirebon Larang / Carbon, Kesulthanan Adipati Gerbang Hilir, Kesulthanan Sumedang Larang, Kesulthanan Adipati Pajang, Kesulthanan Surabaya, Kesulthanan Giri Kedaton hingga 
mempora-porandakanya, dan juga mencoba mengexpansi Kesulthanan Banten tapi mengalami kegagalan. Kesulthanan Mataram Islam pada akhirnya mengalami perpecahan Kesulthanan Kasunanan Surakarta Hadiningrat (Kesulthanan Solo), Kesulthanan Mangkunegaran (Kesulthanan Solo), Kesulthanan Kasultanan Ngayogyakarta Hadiningrat (Kesulthanan Yogyakarta), dan Kesulthanan Pakualaman (Kesulthanan Yogyakarta).

21. Nama Kerajaan : Kesulthanan Adipati Gerbang Hilir Dinasti Yang Memerintah: Ba 'Alwi Dinasti Azmatkhan. Lokasi Kerajaan : Kota Kuningan, Jawa Barat (Indonesia) Kekusaan Kerajaan : Kota : Kuningan, Galuh Kawali Ciamis, dan Panjalu

Keterangan Sejarah : Diberikan kekuasan pada Pageran Suta Jaya keturunan ke 7 Zuriyah Sultan Ratu Haji Sri Himun Syarif Hidayatullah atas Kota : Kuningan, Galuh Kawali Ciamis, dan Panjalu dibawah Kekuasaan Cirebon Larang, pengusaan Mataram Islam, penguasan VOC lalu penguasaan Kolonial Kerajan Belanda (Nederland). Lalu setelah Repbulik Indonesia Serikat menjadi salah satu negara bagian Repbulik Indonesia Serikat dan sekarang hanya menjadi lembaga adat dan kebudayan dalam Negara Kesatuan Republik Indonesia (NKRI)

22. Nama Kerajaan : Kesulthanan Adipati Sukapura

Dinasti Yang Memerintah : Zuriyah Al-Muhqrowi (AlHussaini Persia) tetapi dikenal juga ada tautan Zuriyah pihak wanita Zuriyah Azmatkhan dan Al-Jaelani

Lokasi Kerajaan : Tasikmalaya, Jawa Barat, (Indonesia).

Kekusaan Kerajaan : Tasikmalaya, Jawa Barat, (Indonesia).

23. Nama Kerajaan : Kesulthanan Adipati Tasikmalaya

Dinasti Yang Memerintah : Zuriyah Al-Muhqrowi (AlHussaini Persia) tetapi dikenal juga ada tautan Zuriyah pihak wanita Zuriyah Azmatkhan dan Al-Jaelani

Lokasi Kerajaan : Tasikmalaya, Jawa Barat, (Indonesia).

Kekusaan Kerajaan : Tasikmalaya, Jawa Barat, (Indonesia).

24. Nama Kerajaan : Kesulthanan Adipati Manonjaya 
Dinasti Yang Memerintah : Zuriyah Al-Muhqrowi (AlHussaini Persia) tetapi dikenal juga ada tautan Zuriyah pihak wanita Zuriyah Azmatkhan dan Al-Jaelani

Lokasi Kerajaan : Tasikmalaya, Jawa Barat, (Indonesia).

Kekusaan Kerajaan : Tasikmalaya, Jawa Barat, (Indonesia).

25. Nama Kerajaan : Kesulthanan Kasunanan Surakarta Hadiningrat (Kesulthanan Solo)

Dinasti Yang Memerintah: Ada tautan Zuriyah pihak wanita Zuriyah Ba 'Alwi Dinasti Azmatkhan.

Lokasi Kerajaan : Solo, Jawa Tengah (Indonesia).

Kekusaan Kerajaan : Solo, Jawa Tengah (Indonesia).

Keterangan Sejarah : Pecahan Kesulthanan Mataram Islam

26. Nama Kerajaan : Kesulthanan Mangkunegaran (Kesulthanan Solo)

Dinasti Yang Memerintah: Ada tautan Zuriyah pihak wanita Zuriyah Ba 'Alwi Dinasti Azmatkhan.

Lokasi Kerajaan : Solo, Jawa Tengah (Indonesia).

Kekusaan Kerajaan : Solo, Jawa Tengah (Indonesia).

Keterangan Sejarah : Pecahan Kesulthanan Mataram Islam

27. Nama Kerajaan : Kesulthanan Kasultanan Ngayogyakarta Hadiningrat (Kesulthanan Yogyakarta)

Dinasti Yang Memerintah: Ada tautan Zuriyah pihak wanita Zuriyah Ba 'Alwi Dinasti Azmatkhan.

Lokasi Kerajaan : Yogyakarta (Indonesia).

Kekusaan Kerajaan : Yogyakarta (Indonesia).

Keterangan Sejarah : Pecahan Kesulthanan Mataram Islam

28. Nama Kerajaan : Kesulthanan Pakualaman (Kesulthanan Yogyakarta)

Dinasti Yang Memerintah: Ada tautan Zuriyah pihak wanita Zuriyah Ba 'Alwi Dinasti Azmatkhan.

Lokasi Kerajaan : Yogyakarta (Indonesia).

Kekusaan Kerajaan : Yogyakarta (Indonesia).

Keterangan Sejarah : Pecahan Kesulthanan Mataram Islam

29. Nama Kerajaan : Kesulthanan Adipati Bagelen

Dinasti Yang Memerintah: Ada tutan Zuriyah pihak wanita Zuriyah Ba 'Alwi Dinasti Azmatkhan.

Lokasi Kerajaan : Bagelen, Jawa Timur (Indonesia).

Kekusaan Kerajaan : Bagelen, Jawa Timur (Indonesia). 
Keterangan Sejarah : Adipati (Negara Bawahan) Kesultanan Mataram Islam lalu dikuasai VOC lalu penguasaan Kolonial Kerajan Belanda (Nederland). Lalu setelah Repbulik Indonesia Serikat menjadi salah satu negara bagian Repbulik Indonesia Serikat dan sekarang hanya menjadi lembaga adat dan kebudayan dalam Negara Kesatuan Republik Indonesia (NKRI).

30. Nama Kerajaan : Kesulthanan Adipati Panembahan Sumenep

Dinasti Yang Memerintah: Ada tautan Zuriyah pihak wanita Zuriyah Ba 'Alwi Dinasti Azmatkhan.

Lokasi Kerajaan : Madura, Jawa Timur (Indonesia).

Kekusaan Kerajaan : Madura, Jawa Timur (Indonesia).

Keterangan Sejarah : Kerajaan Panembahan Sumenep Kuno Madura ini pernah menjadi Adipati / Kerajaan bawahan Majapahit Hindu lalu dibawah Kesultanan Demak Bintoro lalu dibawah Kesulthanan Mataram Islam lalu dibawah VOC dan pada akhirnya dibawah kekuasaan pemerintahan Kolonialisme Kerajaan Belanda / Kerajaan Nederland. Lalu setelah Repbulik Indonesia Serikat menjadi salah satu negara bagian Repbulik Indonesia Serikat dan sekarang hanya menjadi lembaga adat dan kebudayan dalam Negara Kesatuan Republik Indonesia (NKRI)

31. Nama Kerajaan : Kesulthanan Aceh Darusalam

Dinasti Yang Memerintah: Zuriyah Al-Husaini (sama degan Kesulthanan Perlak, tetapi pada saat Dipimpin oleh Syaid Ibrahim Jamalulail (Zuriyah Ba ' Alwi jamalulail) hanya 16991726) setelah dikenal juga pihak wanita Zuriyah Ba ' Alwi Jamalulail.

Lokasi Kerajaan : Banda Aceh (Indonesia).

Kekusaan Kerajaan : Propinsi Aceh (Indonesia).

Keterangan Sejarah : Setelah itu Kesulthanan Aceh dikuasai VOC lalu penguasaan Kolonial Kerajan Belanda (Nederland). Lalu setelah Repbulik Indonesia Serikat menjadi salah satu negara bagian Repbulik Indonesia Serikat dan sekarang hanya menjadi lembaga adat dan kebudayan dalam Negara Kesatuan Republik Indonesia (NKRI).

32. Nama Kerajaan : Kesulthanan SamuZuriyaha Pasai 
Dinasti Yang Memerintah: Zuriyah Al-Husaini (sama degan Kesulthanan Perlak).

Lokasi Kerajaan : Aceh, (Indonesia).

Kekusaan Kerajaan : Aceh (Indonesia).

34. Nama Kerajaan : Kesulthanan Palembang Darusalam

Dinasti Yang Memerintah: Zuriyah $\mathrm{Ba}$ 'Alwi Dinasti Azmatkhan.

Lokasi Kerajaan : Kota Palembang, Sumatra Selatan (Indonesia).

Kekusaan Kerajaan : Propinsi Palembang Sumatra Selatan (Indonesia).

Keterangan Sejarah : Setelah itu lalu dikuasai VOC lalu penguasaan Kolonial Kerajan Belanda (Nederland). Lalu setelah Repbulik Indonesia Serikat menjadi salah satu negara bagian Repbulik Indonesia Serikat dan sekarang hanya menjadi lembaga adat dan kebudayan dalam Negara Kesatuan Republik Indonesia (NKRI).

35. Nama Kerajaan : Kesulthanan Siak Sri InZuriyahapura

Dinasti Yang Memerintah: Zuriyah Ba 'Alwi Sahabubudin Bana Hasan (Dikenal Juga Al-Shahab), tetapi dikenal juga ada tautan Zuriyah garis wanita Zuriyah Ba 'Alwi Jamalulail.

Lokasi Kerajaan : Riau (Indonesia).

Kekusaan Kerajaan : Propinsi Palembang Sumatra Selatan (Indonesia).

Keterangan Sejarah : Setelah itu lalu dikuasai VOC lalu penguasaan Kolonial Kerajan Belanda (Nederland). Lalu setelah Repbulik Indonesia Serikat menjadi salah satu negara bagian Repbulik Indonesia Serikat dan sekarang hanya menjadi lembaga adat dan kebudayan dalam Negara Kesatuan Republik Indonesia (NKRI).

36. Nama Kerajaan : Kesulthanan Riau

Dinasti Yang Memerintah: Ada tautan Zuriyah pihak wanita Zuriyah Ba 'Alwi AlayZuriyahus-Assegaf.

Lokasi Kerajaan : Propinsi Riau (Indonesia).

Kekusaan Kerajaan : Propinsi Riau (Indonesia).

Keterangan Sejarah : Setelah itu lalu dikuasai VOC lalu penguasaan Kolonial Kerajan Belanda (Nederland). Lalu setelah Repbulik Indonesia Serikat menjadi salah satu negara 
bagian Repbulik Indonesia Serikat dan sekarang hanya menjadi lembaga adat dan kebudayan dalam Negara Kesatuan Republik Indonesia (NKRI).

37. Nama Kerajaan : Kesulthanan Pontianak

Dinasti Yang Memerintah: Ada tautan Zuriyah pihak wanita Zuriyah Ba ' Alwi Jamalulail lalu disambung oleh Ba ' Alwi Al-GhaZuriyahi dikarenakan pernikahan.

Lokasi Kerajaan : Propinsi Pontianak, Kalimantan Barat (Indonesia).

Kekusaan Kerajaan : Pontianak, Kalimantan Barat (Indonesia). Keterangan Sejarah : Setelah itu lalu dikuasai VOC lalu penguasaan Kolonial Kerajan Belanda (Nederland). Lalu setelah Repbulik Indonesia Serikat menjadi salah satu negara bagian Repbulik Indonesia Serikat dan sekarang hanya menjadi lembaga adat dan kebudayan dalam Negara Kesatuan Republik Indonesia (NKRI).

38. Nama Kerajaan : Kesulthanan Kubu

Dinasti Yang Memerintah: Zuriyah Ba ' Alwi Al-GhaZuriyahi. Lokasi Kerajaan : Propinsi Pontianak, Kalimantan Barat (Indonesia).

Kekusaan Kerajaan : Propinsi Pontianak, Kalimantan Barat (Indonesia).

Keterangan Sejarah : Setelah itu lalu dikuasai VOC lalu penguasaan Kolonial Kerajan Belanda (Nederland). Lalu setelah Repbulik Indonesia Serikat menjadi salah satu negara bagian Repbulik Indonesia Serikat dan sekarang hanya menjadi lembaga adat dan kebudayan dalam Negara Kesatuan Republik Indonesia (NKRI).

39. Nama Kerajaan : Kesulthanan Sabamban

Dinasti Yang Memerintah: : Zuriyah Ba ' Alwi AlayZuriyahus-Assegaf.

Lokasi Kerajaan : Kalimantan Selatan (Indonesia).

Kekusaan Kerajaan : Kalimantan Selatan (Indonesia).

40. Nama Kerajaan : Kesulthanan Ternate

Dinasti Yang Memerintah: Ba 'Alwi Dinasti Azmatkhan.

Lokasi Kerajaan : Kota Ternate, Propinsi Maluku Utara (Indonesia). 
Kekusaan Kerajaan : Kota Ternate, Propinsi Maluku Utara (Indonesia).

Keterangan Sejarah : Kesulthanan Ternate yang hidup dengan damai dengan Kerajaan Tidore dipecah belah oleh VOC dengan politik adu domba VOC hingga pada akhirnya Kesulthanan Ternate dikuasai VOC lalu penguasaan Kolonial Kerajan Belanda (Nederland). Lalu setelah Repbulik Indonesia Serikat menjadi salah satu negara bagian Repbulik Indonesia Serikat dan sekarang hanya menjadi lembaga adat dan kebudayan dalam Negara Kesatuan Republik Indonesia (NKRI).

41. Nama Kerajaan : Kesulthanan Gowa Tallo

Dinasti Yang Memerintah : pernah pada masa tertentu dipimpin Zuriyah Ba 'Alwi Aidit.

Lokasi Kerajaan : Makasar (Bugis), Sulawesi Selatan (Indonesia).

Keterangan Sejarah : Kerajaan Gowa Tallo yang kaya akan rempah-rempah adalah dua Kerajaan yang berbeda asalnya yakni Kerajaan Gowa dan Tallo yang pada akhirnya bersatu karena persaman darah, visi, misi, adat istiadat, budaya DLL kerajaan ini terkenal oleh armada perangnya Raja yang terkenalnya adalah Sulthan Hasanudin yang bergelar Ayam Jantan Zuriyah Timur yang berhasil mepperluas kekuasanya Zuriyah Makasar (Bugis) sampai ke Sumbawa dan sebagian selatan daerah flores tetapi pada akhirnya harus takluk oleh belanda karena serangan Kerajaan Belanda/Kerajaan Nederland yang di bantu oleh Kerajaan Bone dibawah pimpinan Aru Palaka karena ingin melapaskan diri dari jajahan Kerajaan Gowa Tallo. Kerajaan / Kesulthanan ini baru membawur dengan duriah Alwi setalah generasi-generasi akhir. . Lalu setelah Repbulik Indonesia Serikat menjadi salah satu negara bagian Repbulik Indonesia Serikat dan sekarang hanya menjadi lembaga adat dan kebudayan dalam Negara Kesatuan Republik Indonesia (NKRI).

42. Nama Kerajaan : Kesulthanan Kelantan (Malaysia)

Dinasti Yang Memerintah: Zuriyah $\mathrm{Ba}$ 'Alwi Dinasti Azmatkhan.

Lokasi Kerajaan : Negara bagian Kelantan (Malaysia). 
Kekusaan Kerajaan : Negara bagian Kelantan (Malaysia). Keterangan Sejarah : Kesulthanan Kelantan (Malaysia) pernah ditaklukan oleh Kerajaan Inggris hinga pada akhirnya diberikan kemerdekaan dibawah kekuasaan Inggris (Dominion) yang tergabung dalam Negara kesatuan Malaysia yang mempunyai 11 Propinsi yang 9 Propinsinya dikuasai oleh Yang Dipertuan Agoeng Malaysia (para Sulthan).

43. Nama Kerajaan : Kesulthanan Perlis (Malaysia)

Dinasti Yang Memerintah: Ada tautan Zuriyah pihak wanita Zuriyah Ba 'Alwi Jamalulail.

Lokasi Kerajaan : Negara bagian Perlis (Malaysia).

Kekusaan Kerajaan : Negara bagian Perlis (Malaysia).

Keterangan Sejarah : Kesulthanan Perlis (Malaysia) pernah ditaklukan oleh Kerajaan Inggris hinga pada akhirnya diberikan kemerdekaan dibawah kekuasaan Inggris (Dominion) yang tergabung dalam Negara kesatuan Malaysia yang mempunyai 11 Propinsi yang 9 Propinsinya dikuasai oleh Yang Dipertuan Agoeng Malaysia (para Sulthan).

44. Nama Kerajaan : Kesulthanan Negri Sembilan (Malaysia)

Dinasti Yang Memerintah: Zuriyah dzuriah Syekh Abdul Qodir Jaelani (Belum diketahui apakah sultan ataukah bansawannya)

Lokasi Kerajaan : Negara bagian Negri Sembilan (Malaysia). Kekusaan Kerajaan : Negara bagian Negri Sembilan (Malaysia).

Keterangan Sejarah : Kesulthanan Negri Sembilan (Malaysia) pernah ditaklukan oleh Kerajaan Inggris hinga pada akhirnya diberikan kemerdekaan dibawah kekuasaan Inggris (Dominion) yang tergabung dalam Negara kesatuan Malaysia yang mempunyai 11 Propinsi yang 9 Propinsinya dikuasai oleh Yang Dipertuan Agoeng Malaysia (para Sulthan).

45. Nama Kerajaan : Kesulthanan Johor (Malaysia)

Dinasti Yang Memerintah: Zuriyah Ba 'Alwi AlayZuriyahusAssegaf.

Lokasi Kerajaan : Negara bagian Johor (Malaysia)

Kekusaan Kerajaan : Negara bagian Johor (Malaysia) 
Keterangan Sejarah : Kesulthanan Johor (Malaysia) pernah ditaklukan oleh Kerajaan Inggris hinga pada akhirnya diberikan kemerdekaan dibawah kekuasaan Inggris (Dominion) yang tergabung dalam Negara kesatuan Malaysia yang mempunyai 11 Propinsi yang 9 Propinsinya dikuasai oleh Yang Dipertuan Agoeng Malaysia (para Sulthan).

46. Nama Kerajaan : Kesulthanan Trengganu (Malaysia)

Dinasti Yang Memerintah: Zuriyah Ba 'Alwi AlayZuriyahusAssegaf.

Lokasi Kerajaan : Negara bagian Trengganu (Malaysia).

Kekusaan Kerajaan : Negara bagian Trengganu (Malaysia).

Keterangan Sejarah : Kesulthanan Trengganu (Malaysia) pernah ditaklukan oleh Kerajaan Inggris hinga pada akhirnya diberikan kemerdekaan dibawah kekuasaan Inggris (Dominion) yang tergabung dalam Negara kesatuan Malaysia yang mempunyai 11 Propinsi yang 9 Propinsinya dikuasai oleh Yang Dipertuan Agoeng Malaysia (para Sulthan).

47. Nama Kerajaan : Kesulthanan Pahang (Malaysia)

Dinasti Yang Memerintah: Zuriyah Ba ' Alwi AlayZuriyahusAssegaf.

Lokasi Kerajaan : Negara bagian Pahang (Malaysia).

Kekusaan Kerajaan : Negara bagian Pahang (Malaysia).

Keterangan Sejarah : Kesulthanan Pahang (Malaysia) pernah ditaklukan oleh Kerajaan Inggris hinga pada akhirnya diberikan kemerdekaan dibawah kekuasaan Inggris (Dominion) yang tergabung dalam Negara kesatuan Malaysia yang mempunyai 11 Propinsi yang 9 Propinsinya dikuasai oleh Yang Dipertuan Agoeng Malaysia (para Sulthan).

48. Nama Kerajaan : Kesulthanan Selangor (Malaysia)

Dinasti Yang Memerintah: Ada tautan Zuriyah pihak wanita Zuriyah Ba 'Alwi AlayZuriyahus-Assegaf.

Lokasi Kerajaan : Negara bagian Selangor (Malaysia).

Kekusaan Kerajaan : Negara bagian Selangor (Malaysia).

Keterangan Sejarah : Kesulthanan Selangor (Malaysia) pernah ditaklukan oleh Kerajaan Inggris hinga pada akhirnya diberikan kemerdekaan dibawah kekuasaan Inggris (Dominion) yang tergabung dalam Negara kesatuan Malaysia yang 
mempunyai 11 Propinsi yang 9 Propinsinya dikuasai oleh Yang Dipertuan Agoeng Malaysia (para Sulthan).

49. Nama Kerajaan : Kesulthanan Perak (Malaysia)

Dinasti Yang Memerintah: Zuriyah Ba 'Alwi Jamalulail.

Lokasi Kerajaan : Negara bagian Perak (Malaysia).

Kekusaan Kerajaan : Negara bagian Perak (Malaysia).

Keterangan Sejarah : Kesulthanan Perak (Malaysia pernah ditaklukan oleh Kerajaan Inggris hinga pada akhirnya diberikan kemerdekaan dibawah kekuasaan Inggris (Dominion) yang tergabung dalam Negara kesatuan Malaysia yang mempunyai 11 Propinsi yang 9 Propinsinya dikuasai oleh Yang Dipertuan Agoeng Malaysia (para Sulthan).

50. Nama Kerajaan : Kesulthanan Kedah (Malaysia)

Dinasti Yang Memerintah: Ada tautan Zuriyah pihak wanita Zuriyah Ba 'Alwi Dinasti Azmatkhan.

Lokasi Kerajaan : Negara bagian Kedah (Malaysia).

Kekusaan Kerajaan : Negara bagian Kedah (Malaysia).

Keterangan Sejarah : Kesulthanan Kedah (Malaysia) pernah ditaklukan oleh Kerajaan Inggris hinga pada akhirnya diberikan kemerdekaan dibawah kekuasaan Inggris (Dominion) yang tergabung dalam Negara kesatuan Malaysia yang mempunyai 11 Propinsi yang 9 Propinsinya dikuasai oleh Yang Dipertuan Agoeng Malaysia (para Sulthan).

51. Nama Kerajaan : Kesulthanan Sulu (Philipina)

Dinasti Yang Memerintah: Zuriyah Ba ' Alwi Syaid Abdullah bin Alwi Amil Faqih (Ba' Alawiy).

Lokasi Kerajaan : Sulu (Philipina).

Kekusaan Kerajaan : Sulu (Philipina).

Keterangan Sejarah : Kesulthanan Sulu (Philipina) hancur oleh expansi Portugis, Prancis, Spanyol, dan Amerika Serikat hinga banyak umat Islam yang dibantai kecuali bila memeluk agama Kristen Katholik bila ingin bertahan hidup.

52. Nama Kerajaan : Kesulthanan Maguindanao (Philipina)

Dinasti Yang Memerintah: Zuriyah Ba 'Alwi Syaid Abdullah bin Alwi Amil Faqih (Ba 'Alawiy).

Lokasi Kerajaan : Maguindanao (Philipina).

Kekusaan Kerajaan : Maguindanao (Philipina). 
Keterangan Sejarah : Kesulthanan Maguindanao (Philipina) hancur oleh expansi Portugis, Prancis, Spanyol, dan Amerika Serikat hinga banyak umat Islam yang dibantai kecuali bila memeluk agama Kristen Katholik bila ingin bertahan hidup.

53. Nama Kerajaan : Kesulthana Kutai Mulawarman

Dinasti Yang Memerintah : Ada tautan Zuriyah pihak wanita Zuriyah Ba' Alwi Assegaf dan Baroqbah

Lokasi Kera Kjaan : Kutai Timur/Kalimantan Timur (Indonesia).

54. Nama Kerajaan : Kesulthanan Adipati Bangkalan Madura

Dinasti Yang Memerintah: Ada tautan Zuriyah pihak wanita Zuriyah Ba 'Alwi Dinasti Azmatkhan.

Lokasi Kerajaan : Madura, Jawa Timur (Indonesia).

Kekusaan Kerajaan : Madura, Jawa Timur (Indonesia).

Keterangan Sejarah : Adipati Zuriyah Kesulthanan Mataram Islam $^{29}$

Hubungan Kerajaan Campa dengan Kerajaan di Jawa tercatat bahwa Raden Jaka Alit, yang juga bernama Arya Angkawijaya, putra Prabu Briwijaya dilahirkan dari isteri permaisuri yang tertua bernama Dewi Tapen, pada tahun Dal 1351, menggantikan ayahnya menjadi raja Majapahit ke-7, dan ia bergelar Sang Prabu Brawijaya $\mathrm{V}$ yang terakhir. Ia beristeri dua yang tua bernama Ratu Andrawi putri asli dari negara Campa Tanah Hindu Barat. Adapun permaisuri yang muda namanya Dyah Wandhansari, putri boyongan dari negara Wandhan juga Tanah Hindu. Sang Prabu Brawijaya mepunyai banyak selir yang masing-masing mempunyai putra, yang berjumlah 117 orang. Salah satu putri dari permaisurinya, putri Campa, Ratu Retna Pembayudigolon, dinamai juga Sekar Kedhaton. Ratu Retna diperisteri Prabu Handayaningrat di Pengging, melahirkan putra, Kiyai Ageng Tingkir. Ia juga dipanggil Mas Karebet, dan Jaka Tingkir. Setelah menjadi raja dan beristana di Pajang, ia diberi gelar Sultan Hadiwijaya. ${ }^{30}$

Keturunan Ratu Andrawi, Putri Campa dari perkawinan Prabu Brawijaya V yang terakhir Majapahit, adalah Sultan Pajang/Jaka Tingkir, sampai pada K. Ahmad Mutamakkin (lahir.1645-an). Dapat dilihat silsilah Ahmad mutamakkin yang bersambung pada raja-raja Majapahit sebagai berikut: Prabu Wijaya IV, Prabu Wijaya V, Ratu Retna Pembayun, Ki Ageng Pengging, Sultan 
Pajang/Jaka Tingkir, Sunan Benawa Sumahadiningrat, Sunan Benawa II Sumahadinegara, Syaikh Ahmad Mutamakkin Sumahadiwijaya Ki Cebolek ${ }^{31}$

Campa muncul dalam sejarah Singosari di abad ke 13 Masehi. Ketika raja Kertanegara berkuasa di Singosari, tahun 1275M beliau menggagas ekspedisi militer ke tanah Melayu dalam upaya penaklukan Sriwijaya dan menjalin persekutuan dengan Campa. Ekspedisi militer yang terkenal dengan nama "Ekspedisi Pamalayu" tersebut selain berhasil menghancurkan Sriwijaya, melakukan ekspansi wilayah dengan menguasai Sumatera, Bakulapura (Kalimantan Barat), Sunda (Jawa Barat), Madura, Bali, dan Gurun (Maluku), Kertanegara juga berhasil memperluas pengaruhnya di Campa melalui perkawinan adik perempuannya dengan raja Campa ${ }^{32}$.

Menurut sejarah di Jawa seorang ulama yang bernama Jamaluddin Husain Akbar, di Jawa dikenal dengan nama Jumadil Kubra, adalah orang tua Malik Ibrahim, dan Ibrahim Asmoro yang wafat makamkan di Tuban. Sedangkan Maulana Ishak yang dinikahi Brawijaya V adalah putra Ibrahim Asmoro. Semua yang dikenal Wali Songo adalah keturunan dari Jumadil Kubra, yang kemudian mendirikan ksultanan, seperti Demak, Cerbon, Banten, Palembang, Ternate dan Bintuni, di Fak-Fak, Papua Barat.

\footnotetext{
${ }^{1}$ Abdullah, Taufik, "Islam dan Pembentukan Tradisi di Asia Tenggara: Sebuah Perspektif Perbandingan", dalam Taufik Abdullah dan Sharon Shiddique (Eds.), Tradisi dan Kebangkitan Islam di Asia Tenggara, Jakarta: LP3ES, 1989, h.x

${ }^{2}$ Ahmad Ibrahim (dkk). 'Readings on Islam in Southeast Asia', 1985. Diter-jemahkan oleh Hasan Basri dengan judul Islam di Asia Tenggara: Perkembangan Kontemporer. Jakarta: LP3ES, Cet. I, 1990.

${ }^{3}$ Abdullah, Taufik, "Islam dan Pembentukan Tradisi di Asia Tenggara: Sebuah Perspektif Perbandingan", dalam Taufik Abdullah dan Sharon Shiddique (Eds.), Tradisi dan Kebangkitan Islam di Asia Tenggara, Jakarta: LP3ES, 1989.

${ }^{4}$ Azyumardi, Renaisans Islam Asia Tenggara, Sejarah Wacana dan Kekuasaan, Bandung: Remaja Rosdakarya, 2000, h.3

${ }^{5}$ Ahmad Ibrahim (dkk). 'Readings on Islam in Southeast Asia', 1985. Diter jemahkan oleh Hasan Basri dengan judul Islam di Asia Tenggara: Perkembangan Kontemporer. Jakarta: LP3ES, Cet. I, 1990, h. 134.

${ }^{6}$ Ajid Thohir. Studi Kawasan Dunia Islam Perspektif Etno-Linguistik dan Geo-Politik. Jakarta: Rajawali Pers, 2009, h. 369

${ }^{7}$ Agus Sunyoto. Wali Songo: Rekonstruksi Sejarah yang Disingkirkan. Tangerang: Trans Pustaka, Cet. I., 2011, h 246 249 8
}

${ }^{9}$ Agus Sunyoto. Wali Songo: Rekonstruksi Sejarah yang Disingkirkan. Tangerang: Trans Pustaka, Cet. I., 2011, h 15, 45, dan 160. 
${ }^{10}$ Liang Liji. Dari Relasi Upeti ke Mitra Strategis: 2000 Tahun Pejalanan Hubungan Tiongkok-Indonesia. Jakara: Buku Kompas, 2012, h.28 29.

${ }^{11}$ Agus Sunyoto. Wali Songo: Rekonstruksi Sejarah yang Disingkirkan. Tangerang: Trans Pustaka, Cet. I., 2011, h34.

${ }^{12}$ Al Attas, Syed Muhammad Naguibs. The Mystycism of Hamzah Fansuri. Kuala Lumpur: University of Malaya Press, 1970.

${ }^{13}$ Arsyad Al Banjari. Sabil al-Muhtadin li al-Tafaquh fi al-Din. Semarang: Toha Putra, t.th, h.3

${ }^{14}$ Abdushamad al-Palimbani. Siyar al-Salikin. Indonesia: Dar Ihya sl-Kutub al Arabiyah, t.th., h.2

${ }^{15}$ Nawawi al Jawi. Marh Labid Tafsir al-Nawawi. Surabaya: al Hidayah, t.th, h.1

16 Yaitu 1) Karanganyar, 2) Kambang Unglen, 3) Kambang Purun, 4) Kedukan Bukit, 5) Kolam Pinisi, 6) Bukit Siguntang, 7)Talang Kikim, 8)Tanjung Rawa, 9) Talang Tuo, 10) Talang Batu.

17Prasasti piagam atau dokumen yang ditulis pada bahan yang keras dan tahan lama. Penemuan prasasti pada sejumlahsitus arkeologi, menandai akhir dari zaman prasejarah, yakni babakan dalam sejarah kuno Indonesia yang masyarakat nya belum mengenal tulisan. Ilmu yang mempelajari prasasti disebut Epigrafi. Kata prasasti berasal dari bahasa Sansekerta, dengan arti sebenarnya adalah "pujian". Namun kemudian dianggap sebagai "piagam, maklumat, surat keputusan, undang undang atau tulisan". Di kalangan arkeolog prasasti disebut inskripsi, sementara di kalangan orang awam disebut batu bertulis atau batu bersurat. http:// www.indonesiakuno.com/2010/06/daftar prasasti-kuno-indonesia.html Downloard, 25 Maret 2011

18 Yaitu 1) Kedukan Bukit, 2) Talang Tuo, 3) Siddahayattra, 4) Kambang Unglen I, 5) Kambang Unglen, 6) Swarnapatta, 7) Talang Batu, 8) Karang Brahi, 9) Kota Kapur, 10) Palas Psemah, 11) Boom Baru, 12) Nalanda, 13) Ligor. Situs dan prasasti di Palembang dapat dibaca seperti Aryandini Novita dan Sondang M. Siregar. Fragmen Peradaban Palembang Tempo Doeloe: Dari Sriwijaya hingga Kolonial. Palembang: Balai Arkeologi Palembang, 2010

19J. Noorduyn, J. 'De Islamisering van Makassar', diterjemahkan S. Gunawan (red) dengan judul Islamisasi Makassar. Djakarta: Bharata, 1972. h.10

20 Muhammad Dliya SyihAb dan Abdullah bin NUh. Al Imâm al Muhâjir Ahmad bin Isâ bin Muhammad 'Aliy al'Aridiy bin Ja'far al-Shadiq, mâlah wa li Naslih wa li al Aimmat min Aslafih min al-Fadâil wa al-Maâsir. Saudi Arabiah: Dâr al-Masyriq, 1980, h. 171

${ }^{21}$ Al Haddad, Sajed Alwi b. Thahir. Sedjarah Perkembangan Islam di Timur Djauh. Djakarta: Addaimi, 1957, h. 26

${ }^{22}$ Krisna Bayu Adji. Raja-Raja Jawa. Yogyakarta: Araska, Cet.I, 2012, h.23

23Fatimi, "Two Letters". Lihat, Azyumardi Azra, Jaringan Ulama Timur Tengah dan Kepulauan Nusantara Abad XVII d XVIII. Bandung: Mizan, Cet.I, 1994, h.42 43.

24 Azyumardi Azra, Jaringan Ulama Timur Tengah dan Kepulauan Nusantara Abad XVII d XVIII. Bandung: Mizan, Cet.I, 1994, h.43

${ }^{25}$ Ditemukan pembagian seperti ini di beberapa buku tentang wali songo, tulisan ini diakses http:// amzadgiwink.blogspot.com/2012/06/wali-songo.html. Akses, 3 Agustus 2012.

26 Ludvik Kalus dan Claude Guillot. Nisan Leran Ji awa Berangka 475 H/1082 M dan Nisan Nisan Terkait. Jakarta: Kepustakaan Populer Gramedia, Cet.I, Maret 2008, h. 12

${ }^{27}$ Lihat seperti http: wikipedia.org/wiki/Majapahit, akses 27 Maret 2013

28 Slamet Muljana. Tafsir Sejarah Nagara Kretagama. Yogyakarta: LkiS, Cet.IV, h. $345,381,383,384$, dan 388. 
${ }^{29}$ Habib Moggi Satya Nurfadhil Azmatkhan Ba'alawi Al Husaini. Kingdoms of Alawiyyin Dynasty http://majeliswalisongo.wordpress.com/2010/07/28/king doms of alawiyyin -dynasty/. Akses, 10 Des 2011

${ }^{30}$ Ki Sabdacarakatama. Ensiklopedia Raja Raja Tanah Jawa: Silsilah Lengkap Raja raja Tanah Jawa dari Prabu Brawijaya V sampai Sri Sultan Hamengku Buwono X. Yogyakarta: Narasi, 2010, h.14 15

31 Zainul Milal Bizawie. Perlawanan Kultural Agama Rakyat: Pemikiran dan Paham Keagamaan Syekh Ahmad al-Mutamakkin dalam Pergumulan Islam dan Tradisi (1645 1740). Jakarta: Yayasan Keris (Kajian Epistemologi dan Antropologi, Agama dan Budaya), Cet. I, 2002. Hlm.104 105 dan 264 265.

32 teknikbermain.blogspot.com sejarah kerajaan singasari terbentuknya.

\section{DAFTAR PUSTAKA}

Abdullah, Taufik, "Islam dan Pembentukan Tradisi di Asia Tenggara: Sebuah Perspektif Perbandingan", dalam Taufik Abdullah dan Sharon Shiddique (Eds.), Tradisi dan Kebangkitan Islam di Asia Tenggara, Jakarta: LP3ES, 1989

Adji , Krisna Bayu. Raja-Raja Jawa. Yogyakarta: Araska, Cet.I, 2012.

Adji , Krisna Bayu. Sejarah Kejayaan Singasari. Yogyakarta: Araska, Cet.I, Agustus 2013.

Adji , Krisna Bayu. Ensiklopedi Istri-Istri Raja Jawa. Yogyakarta: Araska, Cet.I, Februari 2012.

Haddad, Sajed Alwi b. Thahir. Sedjarah Perkembangan Islam di Timur Djauh. Djakarta: Addaimi, 1957/

Attas, Syed Muhammad Naguibs. The Mystycism of Hamzah

Fansuri. Kuala Lumpur: University of Malaya Press, 1970.

Azmatkhan, Ali bin Badri. Dari Kanjeng Sunan Sampai Romo Kiai Syaikhona Muhammad Kholil Bangkalan. Pemakasan: IKAZI (Ikatan Keluarga Azmatkhan Indonesia), Cet. I, 2007. Azra, Azyumardi,, Renaisans Islam Asia Tenggara, Sejarah Wacana dan Kekuasaan, Bandung: Remaja Rosdakarya, 2000.

Azra, Azyumardi. Jaringan Ulama Timur Tengah dan Kepulauan Nusantara Abad XVII d XVIII. Bandung: Mizan, Cet.I, 1994. Banjari, Arsyad. Sabil al-Muhtadin li al-Tafaquh fi al-Din. Semarang: Toha Putra, t.th. 
Bizawie, Zainul Milal. Perlawanan Kultural Agama Rakyat: Pemikiran dan Paham Keagamaan Syekh Ahmad alMutamakkin dalam Pergumulan Islam dan Tradisi (16451740). Jakarta: Yayasan Keris (Kajian Epistemologi dan Antropologi, Agama dan Budaya), Cet. I, 2002.

Drewes, G. J. W..”An Early Japanese Code of Muslim Ethik".

Diterjemahkan oleh Wahyudi, S.Ag dengan judul Perdebatan Walisongo Seputar Makrifatullah. Surabaya: ALFIKR, Cet. I, 2002.

Graff dan Pegeaud. Kerajan-Kerajaan Islam di Jawa: Peralihan dari Majapahit ke Mataram. Jakarta: PT. Grafiti, Cet.I, 1985.

Hamka. Sejarah Umat Islam IV. Jakarta: Bulan Bintang, Cet.II, 1976

Husaini, Habib Moggi Satya Nurfadhil Azmatkhan Ba'alawi. Kingdoms Of Alawiyyin Dynasty http://majeliswalisongo. wordpress.com/2010/07/28/kingdoms-of-alawiyyin-dynasty/.

Ibrahim ,Ahmad, (dkk). 'Readings on Islam in Southeast Asia', 1985. Diterjemahkan oleh Hasan Basri dengan judul Islam di Asia Tenggara: Perkembangan Kontemporer. Jakarta: LP3ES, Cet. I, 1990.

Idrus, Muhammad Hasan. 'Ayaraf Hadramaut' ditrjemahkan oleh Aly Yahya dengan Judul Penyebar Islam di Asia Tenggara. JakartaLentera Basritama, 1996

Lapian, Adrian B.. Pelayaran dan Perniagaan Nusantara Abad ke16 dan 17. Depok: Komunitas Bambu, cet.I, 2008.

Liji, Liang. Dari Relasi Upeti ke Mitra Strategis: 2000 Tahun Pejalanan Hubungan Tiongkok-Indonesia. Jakara: Buku Kompas, 2012.

Muljana, Slamet. Runtuhnya kerajaan Hindu-Jawa dan timbulnya negara-negara Islam di Nusantara. Yogyakarta: PT LKiS Pelangi Aksara. 2005.

Muljana, Slamet. Tafsir Sejarah Nagara Kretagama. Yogyakarta: LkiS, Cet.IV

Mushthafa, Bisyri. Tarikh al-Auliya': Tarikh Wali Songo. Rembang: Menara Kudus, 1372 H/1952.

Nawawi al-Jawi,. Marh Labid Tafsir al-Nawawi. Surabaya: alHidayah, t.th. 
Noorduyn, J. 'De Islamisering van Makassar', diterjemahkan S. Gunawan (red) dengan judul Islamisasi Makassar. Djakarta: Bharata, 1972.

Palimbani, Abdushamad,. Siyar al-Salikin. Indonesia: Dar Ihya slKutub al-Arabiyah, t.th.

Rahman, Ahmad,. Profil Keturunan Arab: Studi tentang Kehidupan Sosial Keagamaan Keturunan Arab di Ujung Pandang, Balai Penelitian Lektur Keagamaan, U. Pandang, 1989, 3

Sabdacarakatama, Ki. Ensiklopedia Raja-Raja Tanah Jawa: Silsilah Lengkap Raja-raja Tanah Jawa dari Prabu Brawijaya $V$ sampai Sri Sultan Hamengku Buwono X. Yogyakarta: Narasi, 2010.

Slamet, Muljana. Tafsir Nagara Kretagama. Yogyakarta: PT LKiS, Cet. IV, 2009.

Sunyoto, Agus. Wali Songo: Rekonstruksi Sejarah yang Disingkirkan. Tangerang: Trans Pustaka, Cet. I., 2011

Syihab, Muhammad Dliya dan Abdullah bin Nuh. Al-Imâm alMuhâjir Ahmad bin Isâ bin Muhammad 'Aliy al'Aridiy bin Ja'far al-Shadiq, mâlah wa li Naslih wa li al-Aimmat min Aslafih min al-Fadâil wa al-Maâsir. Saudi Arabiah: Dâr alMasyriq, 1980.

Thohir, Ajid,. Studi Kawasan Dunia Islam Perspektif EtnoLinguistik dan Geo-Politik. Jakarta: Rajawali Pers, 2009.

\section{Website}

http://id.wikipedia.org/wiki/Kerajaan_Champa. Downloard. http://emasloemiyono.wordpress.com - islam masuk kamboja http://teknikbermain.blogspot.com - sejarah-kerajaan-singasariterbentuknya

http://www.waspada.co.id - kerajaan melayu islam ditelusuri http://amzadgiwink.blogspot.com/2012/06/wali-songo.html. 